\title{
Phytoprotection
}

\section{Policy and Regulations for New Organisms Supporting Sustainable Pest Management in the United States}

\section{Phil Hutton}

Volume 79, numéro 4, 1998

OECD Workshop - Sustainable Pest Management, Safe Utilization of New Organisms in Biological Control. Montréal, Québec, Canada. September 27-30, 1998.

Atelier de l'OCDE - Gestion durable des ennemis des cultures, Utilisation sécuritaire de nouveaux organismes de lutte biologique. Montréal, Québec, Canada. 27-30 Septembre 1998.

URI : https://id.erudit.org/iderudit/706151ar

DOI : https://doi.org/10.7202/706151ar

Aller au sommaire du numéro

Éditeur(s)

Société de protection des plantes du Québec (SPPQ)l

ISSN

0031-9511 (imprimé)

1710-1603 (numérique)

Découvrir la revue

Citer cet article

Hutton, P. (1998). Policy and Regulations for New Organisms Supporting

Sustainable Pest Management in the United States. Phytoprotection, 79(4),

22-25. https://doi.org/10.7202/706151ar d'utilisation que vous pouvez consulter en ligne. 


\title{
Policy and Regulations for New Organisms Supporting Sustainable Pest Management in the United States
}

\author{
Phil Hutton
}

Chief, Microbial Pesticides Branch, Biopesticide and Pollution Prevention Division, Office of Pesticide Programs, United States Environmental Protection Agency, Washington DC, USA

\section{BACKGROUND}

In the United States, three Agencies are involved with the introduction of new organisms into the environment.

1. U.S. Department of Agriculture, Animal and Plant Health Inspection Service (APHIS)

APHIS guards U.S. borders against foreign agricultural pests and diseases, along with searching for and monitoring agricultural diseases and pests. Therefore, for many organisms, an APHIS permit is required for import of the organism into the United States, or for interstate movement of these organisms. APHIS also issues biotechnology permits for recombinant plants either moved into the United States or between states.

\section{Food and Drug Administration (FDA)}

FDA is responsible for the safety of food and feed. FDA is also responsible for the enforcement of pesticide tolerances in food and feed. FDA monitors food and feed and does market basket analysis of pesticide residues.

\section{Environmental Protection Agency (EPA)}

EPA is responsible for the regulation of pesticides in the United States. Therefore, any living organism used to control, repel, or mitigate a pest is regulated by EPA. EPA may register such organisms or exempt them from registration or regulation. Living organisms that are pesticides are generally categorized as microbial pesticides or plant pesticides. Microbial pesticides include any virus, bacteria, fungi, protozoa, alga, or other microorganism used for pest control.

In certain cases, a microbe may be killed prior to use. If the killed microbe is used in its' entirety, EPA regulates the killed microbe on a case-by-case basis depending upon the cell components that result in its' biological activity. If those components are concentrated, then EPA generally regulates that product as a traditional chemical pesticide. Plant-pesticides include the pesticidal substance and the genetic material necessary for its production in a living plant. Macro-organisms (such as predaceous arthropods) and nematodes already regulated by USDA/APHIS have been exempted from EPA regulation. EPA regulates microbial pesticides and plant pesticides under several federal statutes:

1. Federal Insecticide, Fungicide and Rodenticide Act

This act provides for the registration and regulation of pesticides within the United States. It also allows for the issuance of experimental use permits, emergency exemptions, and certain kinds of state registrations.

2. Food, Drug and Cosmetic Act, and the Food Quality Protection Act 
These acts provide for the establishment of tolerances or exemptions from the requirement of a tolerance for levels of pesticides in food or feed.

\section{Endangered Species Act}

Provides for the protection of certain specified endangered species in the United States.

\section{EXPERIENCE, REGULATORY APPROACH}

\section{Experience}

So far, EPA has registered 52 viable and 5 non-viable microbial pesticides ( table 1.) and 7 plant pesticides (table 2.). The first of these was registered in 1948, but the vast majority of these have been registered in the last 10 years. Applications for the registration of microbial pesticides increased sharply after the publication of specific guidelines for the registration of these pests in 1984, and again after their revision in 1988. Additionally, the EPA's stated policy of promoting the registration and use of safer pesticides by expediting the review of such sustainable products gave further stimulation to the industry. In general living organisms as pesticides have been less insulting to man or the environment than their traditional chemical counterparts. This is due in large part to the specificity of these products as compared to broad spectrum chemicals. At the present, review of a complete dossier for a new microbial pesticide takes around 12 months, as compared to 3 years for a conventional chemical pesticide. As of this writing, EPA has 11 pending applications for living microbial pesticides and 2 pending applications for plant-pesticides.

\section{Table 1. Registered Microbial Pesticides in the United States}

\section{BACTERIA}

Bacillus popilliae \& B. lentimorbus

Bacillus thuringiensis subs. kurstaki

Agrobacterium radiobacter $\mathrm{K} 84$

$B$. thuringiensis subs. israelensis

$B$. thuringiensis Berliner

$B$. thuringiensis subs. tenebrionis

P. fluorescens A506

$P$. fluorescens $1629 \mathrm{RS}$

$P$. syringae $742 \mathrm{RS}$

$B$. thuringiensis subs. kurstaki EG2348

$B$. thuringiensis subs. kurstaki EG2424

B. thuringiensis subs. kurstaki EG2371

B. sphaericus

B. subtilis $\mathrm{GBO} 3$

B. thuringiensis subs. aizawai GC-91

$B$. thuringiensis subs. aizawai

Burkholderia cepacia type Wisconsin M36

Streptomyces griseoviridis $\mathrm{K} 61$

$B$. thuringiensis subs. kurstaki BMP123

B. subtilis $\mathrm{MBI} 600$

B. thuringiensis subs. kurstaki EG7673 Lep. toxin

P. syringae ESC 10

$P$. syringae ESC 11

$B$. thuringiensis subs. kurstaki EG7841

$B$. thuringiensis subs. kurstaki EG7826

Burkholderia cepacia type Wisconsin IsoJ82

$B$. thuringiensis subs. kurstaki M200

$B$. thuringiensis subs. kurstaki EG7673 col. toxin

Bacillus cereus Strain BP01

Paecilomyces fumorsoroseus Apopka strain 97 


\section{YEAST}

Candida oleophila I-182

FUNGI

Phytophthora palmivora MWV

Colletotrichum gloeosporioides aeschynomene ATCC 20358

Trichoderma harzianum ATCC 20476

Trichoderma polysporum ATCC 20475

Gliocladium virens G-21

Gliocladium catenulatum J1446

Trichoderma harzianum Rifai KRL-AG2

Lagenidium giganteum

Metarhizium anisopliae ESF1

Puccinia canaliculate (Schweinitz) Langerheim ATCC 40199

Ampelomyces quisqualis M10

Beauveria bassiana GHA

Beauveria bassiana ATCC 74040

\section{PROTOZOA}

Nosema locustae

\section{VIRUSES}

Heliothis Nucleopolyhedrosis virus (NPV)

Douglas fir tussock moth NPV

Gypsy moth NPV

Beet armyworm NPV

Autographa californica NPV

Anagrapha falcifera NPV

Cydia pomonella Granulosis virus

\section{NON-VIABLE MICROBIAL PESTICIDES}

$B$. thuringiensis subs. kurstaki delta-endotoxin in killed $P$. fluorescens

$B$. thuringiensis subs. San Diego delta-endotoxin in killed $P$. fluorescens

B.t. CrylA(c) \& Cry I(c) delta-endotoxin in killed P. fluorescens

Bt CrylC in killed $P$. fluorescens

Killed fermentation solids \& solubles of Myrothecium verrucaria

\section{Table 2. Registered Plant-Pesticides in the United States}

B.t. CryllIA delta-endotoxin and the genetic material necessary for its production in potato

B.t. CrylA(b) delta-endotoxin and the genetic material necessary for its production in corn

B.t. CrylA $(c)$ delta-endotoxin and the genetic material necessary for its production in cotton CrylA(B) delta-endotoxin and the genetic material necessary for its production in corn

$\mathrm{Bt}$. K delta-endotoxin and the genetic material necessary for its production in corn produced by HD-1 gene from plasmid vector pZ01502

Bt. K Cry IA(c) delta-endotoxin and the genetic material necessary for its production in corn

Bt. Tolworthi. Cry 9C delta-endotoxin and the genetic material necessary for its production in corn

\section{Regulatory Approach}

In general, the EPA approach to the registration of microbial and plant pesticides is quite different from that for conventional chemicals. Data require- ments for microbial pesticides revolve around a tiered approach of toxicity and pathogenicity testing using high doses at the initial tier. In addition to characterization and product identity data, as- 
sessments are made of potential toxicity and pathogenicity to humans and selected non-target organisms, including avian, fish, aquatic invertebrates, pollinators and plants. Usually, the applicant submits a thorough literature search along with the submitted data.

Product performance (efficacy) data are generally not required unless the proposed use involves public health pests such as mosquitoes, cockroaches, or aflatoxin-producing fungi. Applicants are responsible for the submission of all data, although waivers of some data requirements may be granted if based upon reasonable scientific information. For this reason, most applications contain a thorough literature search of the known data on a specific organism. EPA does have a laboratory audit program through the Office of Compliance and Enforcement which inspects laboratories to ensure the integrity of the data submitted to the Agency. Specific information on EPA data requirements and microbial testing guidelines (series 885 ) are available from the EPA web site at

http://www.epa.gov/docs/OPPTS Harmonized/885_Microbial_Pesticide_ Test_Guidelines/

Formal established data requirements for plant pesticides in the United States have not as yet been established. However, the following items have been addressed for all of the existing registrations involving proteins from Bacillus thuringiensis:

Product Identity- construct, characterization, markers, vectors

Protein Digestibility

Potential Allergenicity

Expression

Fate

Potential gene transfer

Toxicology

Non-target Organisms

Resistance Management

\section{KEY ISSUES}

\section{Microbial Pesticides}

There are several difficult issues surrounding the registration of microbial pesticides in the U.S. One vexing problem involves the potential toxicity of metabolites from living organisms. In the United States, EPA may ask for specific studies on such metabolites, or require data to quantify the amount of certain metabolites produced by an organism. In some cases, the potential metabolites are well known. However, in other cases, the metabolites may not be known, or if they have been identified then little is known of their respective toxicological profile. Additionally, microbes may produce different metabolites (or different levels of a metabolite) depending upon the substrates available for its growth. This may be true either in production, or after release into the environment. EPA presently responds to these issues on a caseby-case basis rather than through a more consistent data requirement and guideline approach. This has been a most difficult issue for microbial pesticides which are fungi.

A second problem involves the question of how to evaluate the potential for adverse effects to immuno-compromised or otherwise debilitated individuals. This has been the case with a particular bacteria, Burkholderia cepacia. B. cepacia was registered several years ago, with a complete set of data requirements. However, EPA has recently learned about infections from $B$. cepacia occurring in patients with the disease cystic fibrosis. At this time, we have been unable to determine what testing would be appropriate to separate the clinical strains of this organism from those which would not be opportunistic pathogens. This has, in effect, prevented any further development or testing of the organism, even though some of the strains could be quite beneficial in biological control. 